Shumna T. Ye., Fedosieieva O. S., Kamyshnyi O. M. New aspect of studying the mechanisms of development of the lungs ventilation capacity disorders in children with bronchial asthma. Journal of Education, Health and Sport. 2020;10(6):155-170. eISSN $2391-8306$. DOI http://dx.doi.org/10.12775/JEHS.2020.10.06.018

https://apcz.umk.pl/czasopisma/index.php/JEHS/article/view/JEHS.2020.10.06.018

https://zenodo.org/record/3904826

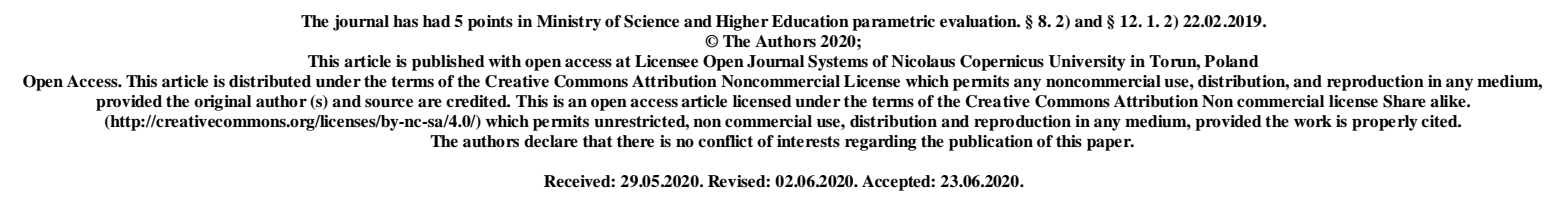

UDK 616.24-092:612.216.2:616.248]053.2-036-07

\title{
NEW ASPECT OF STUDYING THE MECHANISMS OF DEVELOPMENT OF THE LUNGS VENTILATION CAPACITY DISORDERS IN CHILDREN WITH BRONCHIAL ASTHMA
}

\author{
T. Ye. Shumna, O. S. Fedosieieva, O. M. Kamyshnyi \\ Zaporizhzhia State Medical University, Zaporizhzhia, Ukraine
}

Shumna Tamila Yevhenivna, MD, PhD, Doctor of Medical Sciences, Professor of Department

of Faculty Pediatrics, Zaporizhzhia State Medical University, Ukraine; 26 Maiakovskiy avenue, Zaporizhzhia, Ukraine, 69035

Tel .: +38097-854-18-09, +38093-284-90-75, e-mail: tshumnaya72@ gmail.com

Fedosieieva Olena Stanislavivna, postgraduate student of Department

of Faculty Pediatrics, Zaporizhzhia State Medical University, Ukraine; Zaporizhzhia, Ukraine, 26 Maiakovskyi avenue, Zaporizhzhia, Ukraine, 69035

Tel .: +38095-021-00-31, e-mail: xiryrg.niko@gmail.com

Kamyshnyi Oleksandr Mykhalovych, MD, PhD, Doctor of Medical Sciences, Professor

Department of Microbiology, Zaporizhzhia State Medical University, Zaporizhzhia, Ukraine

26 Maiakovskyi avenue, Zaporizhzhia, Ukraine, 69035

Tel .: +38066-926-63-08, e-mail: alexkamyshnyi@gmail.com

\section{Abstract}

Purpose. Study of the pathogenetic role of the polymorphism of the ACTN3 gene (actinin, alpha 3) rs1815739 in the development of lungs ventilation capacity disorders in children with bronchial asthma. 
Materials and methods. To study the polymorphism of ACTN3 gene (actinin, alpha 3) rs 1815739 , the molecular and genetic study of 90 children aged from 6 to 18 years with bronchial asthma, who were passing in-patient treatment at the Allergy Department of the Municipal NonProfit Enterprise "Children's Hospital no.5" of Zaporizhia City Council, and 25 healthy children (control group) was conducted. The external respiration function was studied using a computer spirograph "PULMOREM" TU U 33.1-02066769-005-2002 (Kharkiv). The study of the polymorphism of the ACTN3 gene (actinin, alpha 3) rs1815739 was performed in the Division of Molecular Genetic Researches of the Training Medical Laboratory Center at the Department of Microbiology of Zaporizhia State Medical University in Zaporizhia on the CFX96 ${ }^{\mathrm{TM}}$ Real-Time PCR Detection Systems amplifier (Bio-Rad laboratories Inc., USA) with extraction of DNA from venous blood by means of polymerase-chain reaction. The results of the study were processed using statistical analysis of the license software package Statistica for Windows 6.1.RU, serial number AXXR712D833214SAN5.

Results. The study of the distribution of allelic genes and genotypes of ACTN3 (actinin, alpha 3) polymorphism for rs1815739 showed that among children with bronchial asthma, the homozygous $\mathrm{C} / \mathrm{C}$ genotype was recorded in $37.7 \%$ of cases, heterozygous $\mathrm{C} / \mathrm{T}$ genotype in $40 \%$ of cases, homozygous $\mathrm{T} / \mathrm{T}$ genotype in $22.3 \%$ of cases, while in healthy children, the frequencies of the homozygous $\mathrm{C} / \mathrm{C}(68 \%)$ and $\mathrm{T} / \mathrm{T}(4 \%)$ genotypes were significantly more frequent. The indicators of external respiration function (forced vital capacity (FVC), forced expiratory volume at the 1-second $\left.\left(\mathrm{FEV}_{1}\right)\right)$ in patients with a homozygous $\mathrm{C} / \mathrm{C}$ genotype were significantly lower than in patients with homozygous T/T genotype and were $2.69(1.9 ; 3.49)$ vs. $3.11(2.47 ; 4,14)$ and $2.06(1.6 ; 2.76)$ vs. $2.82(2.02 ; 3.51)$. The patency of large and small bronchi, characterized by spirographic MEF25 and MEF75 indicators, was significantly better in children with bronchial asthma with homozygous $\mathrm{T} / \mathrm{T}$ genotype than in children with $\mathrm{C} / \mathrm{T}$ and $\mathrm{C} / \mathrm{C}$ genotypes $(5.46(4.87 ; 6,31)$ and $2.36(1.89 ; 3.32)$ against $4.54(3.69 ; 5.43)$ and $4.17(3.24 ; 5.44)$, and 1.88 $(1.10 ; 2.56)$ and $1.69(1.16 ; 2.02)$, respectively. In children with bronchial asthma and the C/C and C/T genotypes of ACTN3 gene (actinin, alpha 3) rs1815739 with probable sufficient synthesis of alpha-actinin-3 protein in muscles, a stronger contraction of the respiratory muscles on inhalation is possible, and in patients with the $\mathrm{T} / \mathrm{T}$ genotype, which encodes insufficient synthesis of alpha-actinin-3 protein in the muscles, the muscle contraction is probably less 
pronounced in asthma attacks, which can lead to less pronounced disorders of lungs ventilation capacity.

Conclusions. The study of ACTN3 (actinin, alpha 3) rs1815739 gene polymorphism showed that the $\mathrm{C} / \mathrm{C}$ and $\mathrm{C} / \mathrm{T}$ genotypes were associated with impaired lung ventilation in children with bronchial asthma.

Keywords: gene; polymorphism; alpha-actinin-3; bronchial asthma; lungs ventilation capacity; children.

\title{
НОВИЙ АСПЕКТ ДОСЛІДЖЕННЯ МЕХАНІЗМІВ РОЗВИТКУ ПОРУШЕНЬ ВЕНТИЛЯЦІНОЇ ЗДАТНОСТІ ЛЕГЕНЬ У ДІТЕЙ 3 БРОНХІАЛЬНОЮ АСТМОЮ
}

\author{
Т. С. Шумна, О. С. Федоссєва, О. М. Камишний
}

\section{Запорізький державний медичний університет, Запоріжжя, Україна}

Мета роботи - дослідження патогенетичної ролі поліморфізму гена ACTN3 (actinin, alpha 3) rs1815739 в розвитку порушень вентиляційної здатності легень у дітей 3 бронхіальною астмою.

Матеріали і методи. Для вивчення поліморфізма гена ACTN3 (actinin, alpha 3) rs1815739 було проведено молекулярно-генетичне дослідження 90 дітей з бронхіальною астмою від 6 до 18 років, які перебували на стаціонарному лікуванні в алергологічному відділенні Комунального неприбуткового підприємства «Дитяча лікарня №5» Запорізької міської ради та 25 здорових дітей (контрольна група). Функція зовнішнього дихання досліджувалась 3 використанням комп'ютерного спірографа «PULMOREM» ТУ У 33.102066769-005-2002 (м.Харків). Вивчення поліморфізму гена ACTN3 (actinin, alpha 3) rs1815739 проводилось у відділі молекулярно-генетичних досліджень навчального медиколабораторного центра на кафедрі мікробіології Запорізького державного медичного університету, м. Запоріжжя, на ампліфікаторі CFX96 ${ }^{\mathrm{TM}}$ Real-Time PCR Detection Systems («Bio-Rad laboratories, Inc.», USA) з виділенням ДНК із венозної крові за допомогою полімеразно-ланцюгової реакції. Отримані результати дослідження були оброблені за 
допомогою статистичного аналізу лицензійного пакета програм Statistica for Windows 6.1.RU, серійний номер AXXR712D833214SAN5.

Результати. Досліджння розподілу алельних генів та генотипів поліморфізма ACTN3 (actinin, alpha 3) rs1815739 показало, що серед дітей з бронхіальною астмою, гомозиготний генотип С/C реєструвався в 37,7\% випадках, гетерозиготний генотип С/Т - у $40 \%$; гомозиготний генотип Т/Т - у 22,3\% обстежених, в той час як у здрових дітей частоти гомозиготних генотипів С/C (68\%) та Т/Т (4\%) зустрічались достовірно частіше. Показники функції зовнішнього дихання (форсована життєвої ємність легень (FVC), об'єм форсованого видоху за першу секунду $\left.\left(\mathrm{FEV}_{1}\right)\right)$ у пацієнтів з гомозиготним генотипом С/C були достовірно нижчими, ніж у пацієнтів з гомозиготним генотипом Т/T і склали 2.69 (1.9;3.49) проти 3,11 (2,47;4, 14) та 2.06 (1.6;2.76) проти 2.82 (2.02;3.51). Прохідність крупних та мілких бронхів, що характеризувалась спірографічними показниками $\mathrm{MEF}_{25}$ та $\mathrm{MEF}_{75}$, була достовірно кращою у дітей з бронхіальною астмою з гомозиготним генотипом $\mathrm{T} / \mathrm{T}$, ніж у дітей з генотипами $\mathrm{C} / \mathrm{T}$ та $\mathrm{C} / \mathrm{C}(5.46(4.87 ; 6,31)$ i 2.36 (1.89; 3.32) проти 4.54 $(3.69 ; 5.43)$ i $4.17(3.24 ; 5.44)$ та $1.88(1.10 ; 2.56)$ і $1.69(1.16 ; 2.02)$, відповідно. У дітей 3 бронхіальною астмою з генотипами С/C і C/T гена ACTN3 (actinin, alpha 3) rs1815739 3 імовірним достатнім синтезом білка альфа-актиніну-3 у м'язах, можливе більш сильне скорочення дихальних м'язів при вдихуванні повітря, а у пацієнтів із генотипом Т/Т, який кодує недостатній синтез білка альфа-актиніну-3 у м'язах, при приступі ядухи скорочення м'язів імовірно менш виражене, що може призводити до менш виражених порушень вентиляційної здатності легень.

Висновки. Дослідження поліморфізма гена ACTN3 (actinin, alpha 3) rs1815739 показало, що генотипи $\mathrm{C} / \mathrm{C}$ та $\mathrm{C} / \mathrm{T}$ були асоційовані 3 порушеннями вентиляційної здатності легень у дітей з бронхіальною астмою.

Ключові слова: ген; поліморфізм; альфа-актинін-3; бронхіальна астма; вентиляційна здатність легень; діти. 


\title{
НОВИЙ АСПЕКТ ИЗУЧЕНИЯ МЕХАНИЗМОВ РАЗВИТИЯ НАРУШЕНИЙ ВЕНТИЛЯЦИННОЙ СПОСОБНОСТИ ЛЕГКИХ У ДІТЕЙ С БРОНХИАЛЬНОЙ АСТМОЙ
}

\author{
Т. Е. Шумная, О. С. Федосеева, А. М. Камышный
}

\section{Запорожский государственный медицинский университет, Запорожье, Украина}

Цель работы - изучение патогенетической роли полиморфизма гена ACTN3 (actinin, alpha 3) rs1815739 в развитии нарушений вентиляционной способности легких у детей $з$ бронхиальной астмой.

Материалы и методы. Для изучения полиморфизма гена ACTN3 (actinin, alpha 3) rs1815739 было проведено молекулярно-генетическое исследование 90 детей с бронхиальной астмой от 6 до 18 лет, которые находились на стационарном лечении в аллергологическом отделении Коммунального неприбыльного предприятия «Детская больница №5» Запорожского городского совета и 25 здоровых детей (контрольная группа). Функция внешнего дыхания исследовалась с использованием компьютерного спирографа «PULMOREM» TУ У 33.1-02066769-005-2002 (м.Харків). Изучение полиморфизма гена ACTN3 (actinin, alpha 3) rs1815739 проводилось в отделе молекулярно-генетических исследований ученого медико-лабораторного центра на кафедре микробиологии Запорожского государственного медицинского университета, г. Запорожье, на амплификаторе CFX96 ${ }^{\mathrm{TM}}$ Real-Time PCR Detection Systems («Bio-Rad laboratories, Inc.», USA) с выделением ДНК из венозной крови при помощи полимеразно-цепной реакции. Полученные результаты исследования были обработаны при помощи статистического анализа лицензионного пакета программ Statistica for Windows 6.1.RU, серійний номер AXXR712D833214SAN5.

Результаты. Изучение распределения аллельных генов и генотипов полиморфизма ACTN3 (actinin, alpha 3) rs1815739 показало, что среди детей с бронхиальной астмой, гомозиготный генотипом С/C регистрировался в $37,7 \%$ случаях, гетерозиготный генотип $\mathrm{C} / \mathrm{T}$ - у $40 \%$; гомозиготный генотип Т/T - у $22,3 \%$ обследованных, в то время как у здровых детей частоты гомозиготных генотипов С/C (68\%) и Т/T (4\%) встречались 
достоверно чаще. Показатели функции внешнего дыхания (форсированная жизненная емкость легких (FVC), объем форсованного выдоха за перую секунду $\left.\left(\mathrm{FEV}_{1}\right)\right)$ у пациентов с гомозиготным генотипом С/С были достоверно ниже, чем у пациентов с гомозиготным генотипом Т/Т и составили 2.69 (1.9;3.49) против 3,11 (2,47;4, 14) и 2.06 (1.6;2.76) против 2.82 (2.02;3.51). Проходимость крупных и мелких бронхов, которая характеризовалась спирографическими показателями $\mathrm{MEF}_{25}$ и $\mathrm{MEF}_{75}$, была достоверно лучшей у детей с бронхиальной астмой с гомозиготным генотипом T/T, чем у детей с генотипами $\mathrm{C} / \mathrm{T}$ и $\mathrm{C} / \mathrm{C}$ - $(5.46(4.87 ; 6,31)$ и $2.36(1.89 ; 3.32)$ против 4.54 (3.69;5.43) и 4.17 (3.24; 5.44); 1.88 (1.10; $2.56)$ и 1.69 (1.16;2.02), соответственно. У детей с бронхиальной астмой с генотипами С/С и C/T гена ACTN3 (actinin, alpha 3) rs1815739 с вероятным достаточным синтезом белка альфа-актинина-3 в мышцах, возможно более сильное сокращение дыхательных мышц на вдохе, а у пациентов с генотипом Т/Т, кодирующим недостаточный синтез белка альфаактинина-3 в мышцах, при приступе удушшя сокращения мышц вероятно менее ввражено, что может приводить к менее выраженным нарушениям вентиляционнй способности легких.

Выводы. Изучение полиморфизма гена ACTN3 (actinin, alpha 3) rs1815739 показало, что генотипы $\mathrm{C} / \mathrm{C}$ и $\mathrm{C} / \mathrm{T}$ были асоциированы с нарушениями вентиляционной способности легких у детей с бронхиальной астмой.

\section{Ключевые слова: ген; полиморфизм; альфа-актинин-3; бронхиальная астма; вентиляционная способность легких; дети.}

\section{Introduction}

Bronchial asthma (BA) is the most severe and widespread disease in pediatrics, which necessitates its comprehensive study. Today, all over the world, there is a steady increase in the BA incidence among child population [1]. In Ukraine, the number of patients with BA ranges from 2 to $15 \%$ among child population and is also growing steadily. Thus, according to official statistics data of the Ministry of Healthcare of Ukraine, 37,422 (0.49\%) patients with BA were registered among the child population in 2015 [2]. Today, bronchial asthma is defined as a heterogeneous disease with the development of the most typical clinical sign that is an attack of expiratory suffocation. In this case, the leading role in the formation of an attack of suffocation belongs to bronchospasm with proliferation of myofibroblasts, hypertrophy and hyperplasia of 
unstriated smooth muscle tissue of the bronchi, as one of the components of the morphological features of bronchial asthma $[3,4]$.

In recent years it has been proven that a necessary condition for the development of bronchial asthma is a hereditary predisposition with predominant polygenic inheritances. It is generally accepted that genetic predisposition to bronchial asthma is represented by a combination of genetically independent components of the disease: predisposition to the development of atopy, to the production of Ig E - antibodies and bronchial hyper-reactivity [3]. And as of today, the most significant genes that are associated with predisposition to bronchial asthma have been identified. But, mainly these are genes that cause predisposition to atopy, while it is worth notice the study of genetic predisposition to the development of airway hyperreactivity - the response of the airways in the form of spasm of bronchi smooth muscles to various chemical, physical and pharmacological irritants, especially in children, who live in a large industrial city in conditions of adverse environmental factors [3]. Accordingly, at bronchospasm, the speed of air movement in the narrowed bronchi increases, which is accompanied by an increase in resistance to air flow and at the same time the work of the respiratory muscles increases, especially during exhalation. And here, the main object of respiration regulation is respiratory muscles relating to skeletal muscles. It is the skeletal respiratory muscles that play an active role in the act of inhale and exhale. Thus, when performing a deep inhale or forced exhale, the inspiratory and expiratory muscles must take part. And of course, the deeper an inhale or exhale is, the more muscles should contract: the internal inter-costal muscles and the muscles lifting the ribs, chest, the diaphragm and even the spine extensor muscles [5].

Also, the development of bronchial obstruction is facilitated by the anatomical and physiological features of the respiratory tract of children, among which the most important are the weak development of the muscle fiber of the bronchial wall and incompletely formed respiratory muscles and airway narrowness [6]. And the external respiration function of patients with asthma is provided by the coordinated work of the respiratory system, which includes the lungs, small circle of blood circulation, respiratory regulation system and chest with respiratory muscles [7]. Therefore, the molecular genetic studies to determine the polymorphism of the ACTN3 gene, which is located in the long arm of the $11^{\text {th }}$ chromosome and is responsible for the synthesis of alpha-actinin-3 protein in muscle fibers and metabolism, function, strength and rate 
of muscle contraction, can be useful for further understanding the mechanisms of development of bronchospasm and regulation of respiration in children with bronchial asthma [8].

Purpose. Study of the pathogenetic role of the polymorphism of the ACTN3 gene (actinin, alpha 3) rs1815739 in the development of lungs ventilation capacity disorders in children with bronchial asthma.

Materials and methods. To study the polymorphism of ACTN3 gene (actinin, alpha 3) rs1815739, the molecular and genetic study of 90 children aged from 6 to 18 years with bronchial asthma, who were passing in-patient treatment at the Allergy Department of the Municipal NonProfit Enterprise "Children's Hospital no.5" of Zaporizhia City Council, and 25 healthy children (control group) was conducted. There were no differences in age and sex between children with bronchial asthma and healthy children ( $\mathrm{p}>0.05)$. Parents of all children signed a voluntary consent to participate in the study. Also, all studies were conducted in compliance with the requirements of bioethics with the obtained permission of the Biotic Commission of Zaporizhia State Medical University.

The external respiration function was studied using a computer spirograph "PULMOREM" TU U 33.1-02066769-005-2002 (Kharkiv). The study was performed three times with the definition of indicators: lungs vital capacity $\left(\mathrm{VC}_{\max }\right)$, lungs forced vital capacity (FVC), forced expiratory volume per second $\left(\mathrm{FEV}_{1}\right)$, ratio of $\mathrm{FEV}_{1} \% \mathrm{~F}$ indicators, maximum expiratory flow at 25\%, 50\% and 75\% FVC $\left(\mathrm{MEF}_{25} ; \mathrm{MEF}_{50} ; \mathrm{MEF}_{75}\right)$. Also, when diagnosing bronchial asthma, all patients underwent a bronchodilator test according to the GOLD program [7].

The study of the polymorphism of the ACTN3 gene (actinin, alpha 3) rs1815739 was performed in the Division of Molecular Genetic Researches of the Training Medical Laboratory Center at the Department of Microbiology of Zaporizhia State Medical University in Zaporizhia on the CFX96 ${ }^{\mathrm{TM}}$ Real-Time PCR Detection Systems amplifier (Bio-Rad laboratories Inc., USA) with extraction of DNA from venous blood by means of polymerase-chain reaction (Head of the Division - Head of the Department of Microbiology, Doctor of Medical Sciences, Professor O.M. Kamyshnyi).

The non-parametric statistical method " $2 \times 2$ Table", the Chi-square $(\mathrm{df}=1)$, was used for statistical analysis of data. The medians and inter-quartile intervals were also calculated, and two independent groups were compared according to the Mann-Whitney test, the OR-odds ratio with a $95 \%$ confidence interval. The level of statistical significance $\mathrm{p}<0.05$, at which the differences 
were considered significant, was used for all types of analysis. The results of the study were processed using statistical analysis of the license software package Statistica for Windows 6.1.RU, serial number AXXR712D833214SAN5.

Results. The conducted study of the polymorphism of ACTN3 gene (actinin, alpha 3) rs1815739 in children showed that the allelic genes were distributed almost equally in patients with bronchial asthma. Indeed, the allelic gene $\mathrm{C}$ was found in $57.78 \%$, the $\mathrm{T}$ allele - in $42.22 \%$ of children. In healthy children, the frequency of occurrence of the $\mathrm{C}$ allele was registered significantly more often and amounted to $82 \%$, and the $\mathrm{T}$ allele, significantly less often and amounted to $18 \%$ of cases, respectively.

The study of the distribution of genotypes of ACTN3 (actinin, alpha 3) rs1815739 polymorphism in the respective groups of the examined children is presented in the Figure 1. Thus, the results showed that $37.7 \%$ of children with bronchial asthma had the homozygous $\mathrm{C} / \mathrm{C}$ genotype, which is responsible for sufficient synthesis of alpha-actinin-3 protein in muscles. The homozygous T/T genotype was detected in $22.3 \%$, and heterozygous $\mathrm{C} / \mathrm{T}$ genotype - in $40 \%$ of patients with bronchial asthma. In the group of healthy children, the homozygous $\mathrm{C} / \mathrm{C}$ genotype was registered (68\%) significantly more often than in the main observation group, the homozygous T/T genotype (4\%) - and significantly less often. $28 \%$ of healthy children had the heterozygous $\mathrm{C} / \mathrm{T}$ genotype.

Given that the active role in the act of respiration belongs to skeletal muscles, we decided to study the indicators of external respiratory function, which characterized the ventilation capacity of the lungs, depending on the genotypes of ACTN3 (actinin, alpha 3) rs1815739 polymorphism in children with bronchial asthma. When conducting a spirometric study, which results are presented in the Table 1, we intended to test the hypothesis that patients with bronchial asthma and the $\mathrm{C} / \mathrm{C}$ genotype, which indicated a probable sufficient synthesis of alpha-actinin-3 protein in muscles, should have better indicators of lungs ventilation function than patients with $\mathrm{C} / \mathrm{T}$ and $\mathrm{T} / \mathrm{T}$ genotypes. However, it should be noted at once that no significant differences between the indicators of lungs ventilation function were registered in children with bronchial asthma with $\mathrm{C} / \mathrm{C}$ and $\mathrm{C} / \mathrm{T}$ genotypes. 


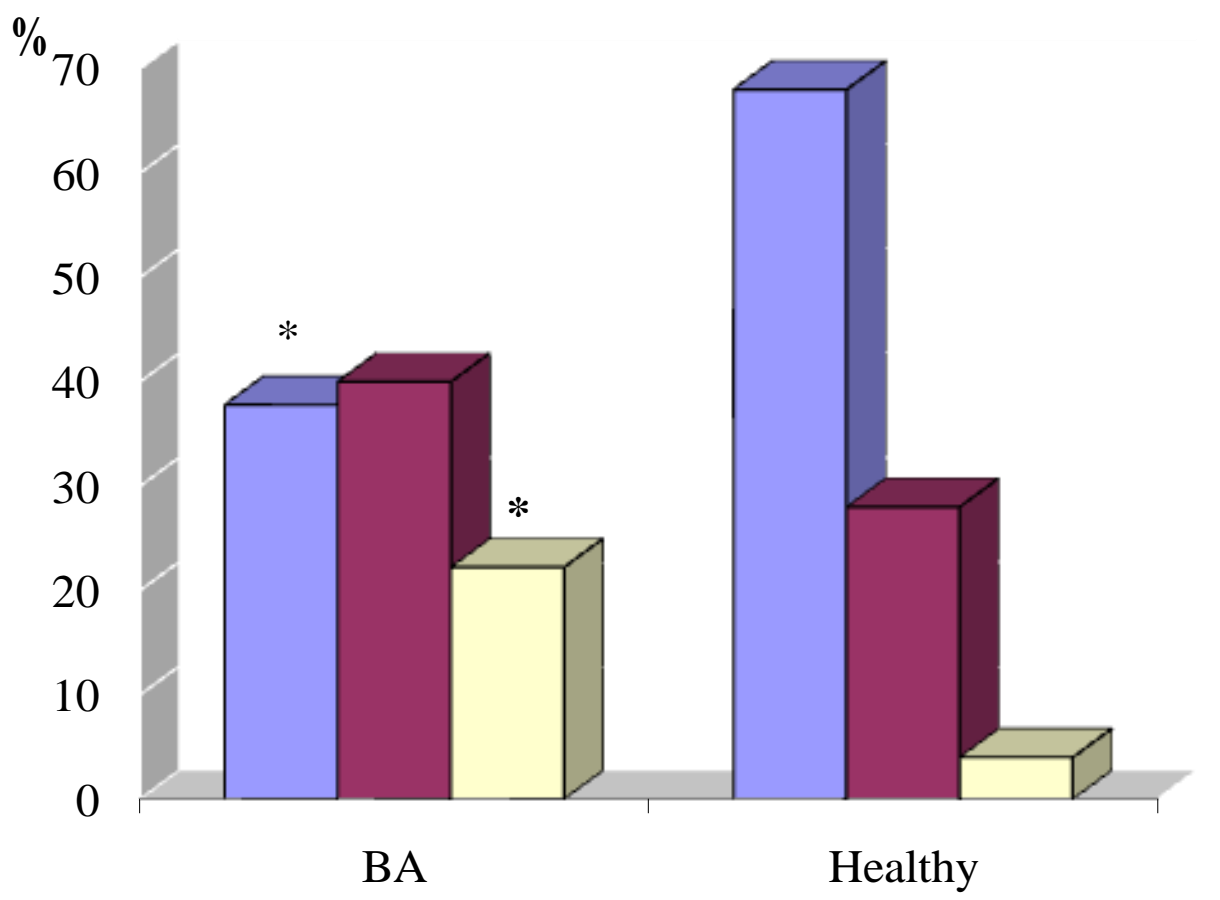

Fig. 1. Frequency of genotypes ACTN3 gene (rs1815739) in children with bronchial asthma (BA) and practically healthy children (Healthy)

(* - p $<0.05$ between the relevant genotypes $(C / C, T / T)$ of children with bronchial asthma and healthy children)

However, on the contrary, regardless of our hypothesis, the indicators of external respiration function in patients with homozygous $\mathrm{C} / \mathrm{C}$ genotype were lower than in patients with homozygous $\mathrm{T} / \mathrm{T}$ genotype. Thus, in children with $\mathrm{C} / \mathrm{C}$ and $\mathrm{T} / \mathrm{T}$ genotypes, the following differences were found: between the indicators of forced vital capacity of the lungs (FVC) - 2.69 $(1.9 ; 3.49)$ against $3.11(2.47 ; 4,14), \mathrm{p}<0,05$; forced expiratory volume at the first second (FEV1) - $2.06(1.6 ; 2.76)$ against $2.82(2.02 ; 3.51), \mathrm{p}<0,05$.

It was also found that in children with bronchial asthma and homozygous T/T genotype, the indicators of the maximum expiratory flow of 25\% $\left(\mathrm{MEF}_{25}\right)$ and $75 \%\left(\mathrm{MEF}_{75}\right)$ of $\mathrm{FVC}$ volume, which characterized the patency of large and small bronchi, were significantly higher than in children with $\mathrm{C} / \mathrm{T}$ and $\mathrm{C} / \mathrm{C}$ genotypes: $5.46(4.87 ; 6.31)$ and $2.36(1.89 ; 3.32)$ against 4.54 $(3.69 ; 5.43)$ and $4.17(3.24 ; 5.44)$ and $1.88(1.10 ; 2.56)$ and $1.69(1.16 ; 2.02)$. 
Table 1

Indicators of external respiratory function in children with bronchial asthma (Me (Q25; Q75))

\begin{tabular}{|c|c|c|c|c|c|c|c|}
\hline Indicators & $\mathrm{FVC}$ & $\mathrm{VC}_{\max }$ & $\mathrm{FEV}_{1}$ & $\mathrm{FEV}_{1} \% \mathrm{~F}$ & $\mathrm{MEF}_{25}$ & $\mathrm{MEF}_{50}$ & $\mathrm{MEF}_{75}$ \\
\hline Genotype T/T & 3,11 & 2,37 & 2,82 & 0,84 & 5,46 & 4,1 & 2,36 \\
$(\mathrm{n}=20)$ & $(2,47 ;$ & $(1,94 ;$ & $(2,02 ;$ & $(0,76 ;$ & $(4,87 ;$ & $(2,94 ;$ & $(1,89 ;$ \\
& $4,14)$ & 3,48 & $3,51)$ & $0,92)$ & $6,31)$ & $4,97)$ & $3,32)$ \\
\hline Genotype C/T & 2,63 & 2,2 & 2,2 & 0,86 & 4,54 & 3,66 & 1,88 \\
$(\mathrm{n}=36)$ & $(1,79 ;$ & $(1,40 ;$ & $(1,59 ;$ & $(0,79 ;$ & $(3,69 ;$ & $(2,71 ;$ & $(1,10 ;$ \\
& $3,46)$ & $2,94)$ & $3,19)$ & $0,91)$ & $5,43)$ & $4,31)$ & $2,56)$ \\
\hline $\mathrm{p}(\mathrm{T} / \mathrm{T}-\mathrm{C} / \mathrm{T})$ & $>0,05$ & $>0,05$ & $>0,05$ & $>0,05$ & $<\mathbf{0 , 0 5}$ & $>0,05$ & $<\mathbf{0 , 0 5}$ \\
\hline Genotype C/C & 2,69 & 2,3 & 2,06 & 0,84 & 4,17 & 3,36 & 1,69 \\
$(\mathrm{n}=34)$ & $(1,9 ;$ & $(1,68 ;$ & $(1,6 ;$ & $(0,69 ;$ & $(3,24 ;$ & $(2,59 ;$ & $(1,16 ;$ \\
& $3,49)$ & $2,69)$ & $2,76)$ & $0,88)$ & $5,44)$ & $4,03)$ & $2,02)$ \\
\hline $\mathrm{p}(\mathrm{T} / \mathrm{T}-\mathrm{C} / \mathrm{C})$ & $<\mathbf{0 , 0 5}$ & $>0,05$ & $<\mathbf{0 , 0 5}$ & $>0,05$ & $<\mathbf{0 , 0 5}$ & $>0,05$ & $<\mathbf{0 , 0 5}$ \\
\hline $\mathrm{p}$ (C/T-C/C) & $>0,05$ & $>0,05$ & $>0,05$ & $>0,05$ & $>0,05$ & $>0,05$ & $>0,05$ \\
\hline
\end{tabular}

However, at the time of examination at the in-patient department, the partially controlled bronchial asthma was significantly more often diagnosed in children with $\mathrm{C} / \mathrm{T}$ genotype than with T/T one ( $75 \%$ vs. $45 \%, \mathrm{p}<0.05)$, with an odds ratio of 3.67 ( $\mathrm{CI}=1.15-11.69)$. Moreover, the incidence of very low indicators of forced vital capacity of the lungs, which depend on the development of the chest and respiratory muscles and reflect the maximum volume of air exhaled during deep (forced) exhalation after a deep breath, was registered in $55.56 \%$ of patients with $\mathrm{C} / \mathrm{T}$ genotype against $25 \%$ - with $\mathrm{T} / \mathrm{T}$ genotype $(\mathrm{p}<0,05)$. In patients with the $\mathrm{C} / \mathrm{C}$ genotype, the partially controlled bronchial asthma was diagnosed in $70.59 \%$ of cases and no significant differences were observed in children with bronchial asthma with other genotypes.

The data obtained as a result of the present study can be explained by the fact that a stronger contraction of the respiratory muscles at the inhale is possible in children with bronchial asthma with genotypes of C/C polymorphism of ACTN3 (actinin, alpha 3) gene rs1815739 with probable sufficient synthesis of alpha-actinin-3 protein in muscles, under conditions of atopy, heterogeneous chronic inflammation and bronchial hyper-reactivity. However, when the air is exhaled, the relaxation of the respiratory muscles may be insufficient on the contrary. At the 
same time, in patients with the T/T genotype, which causes insufficient synthesis of alphaactinin-3 protein in the muscles, the muscle contraction is probably less pronounced during an asthma attack, and the respiratory muscles are more relaxed during exhalation.

\section{Discussion}

According to the literature sources, it is known that the reduction of bronchial myofibrils with the development of bronchospasm occurs during the interaction of myofibrils of actin and myosin muscles $[9,10]$. However, the pathogenetic role of the ACTN3 gene polymorphism (rs1815739) in the development of disorders of the ventilation capacity of the lungs in bronchial asthma was not studied. Traditionally, molecular genetic studies of this gene were performed in athletes to research their genetic predisposition to muscle strength or endurance [11, 12]. At the beginning of the discussion, it is immediately necessary to clarify that in English-language literature sources, the alleles are also designated as $\mathrm{R}$ and $\mathrm{X}$ in order to show that aCTN3 gene polymorphism, arginine $(\mathrm{R})$ at position 577 is replaced by a stop codon (X), while in our study, they are designated as $\mathrm{C}$ and $\mathrm{T}$ [13]. In this case, the homozygous $\mathrm{C} / \mathrm{C}$ or $\mathrm{R} / \mathrm{R}$ genotype is called major, and the homozygous $\mathrm{T} / \mathrm{T}$ or $\mathrm{X} / \mathrm{X}$ genotype is called minor. Thus, while examining the Russian Federation athletes who are engaged in track and field athletics (running, rowing, biathlon, cross-country skiing, cycling, swimming), it was found that the incidence of the T allele of the ACTN3 gene polymorphism (rs1815739) was $48.2 \%, \mathrm{C}$ allele $-51.8 \%, \mathrm{C} / \mathrm{C}$ genotype 29.6\%; C/T genotype - 44.5\%; T/T genotype - 25.9\% [14].

When studying the association between the ACTN3 gene polymorphism (rs1815739) and the athletic ability of Chinese athletes to sprint, where athletes compete in running for short (sprint) distances in the stadium, it was found that a major homozygous genotype was registered in athletes in $42.6 \%$, major heterozygous genotype - in $49.1 \%$, homozygous minor genotype - in $8.3 \%$ of cases. At the incidence of major homozygous and heterozygous genotypes these data almost coincided with the incidence of these genotypes in our study in a group of children with bronchial asthma. At the same time, when comparing the results of our study with the literature data, the dominant major homozygous genotype was registered 1.5 - 2 times more often in our group of healthy children than in Chinese sprinters or people who did not do professional sports [15]. When studying the ACTN3 gene (rs1815739) polymorphism in children living in southern China, the scientists found that in the group of overweight children and in the control group, the frequency of the $\mathrm{C}$ allele was $57.4 \%$ and $58.6 \%$, and $\mathrm{T}$ allele $42.5 \%$ and $41.3 \%$, respectively. 
These data almost coincide with the results of our studies in the group of children with bronchial asthma. But, according to our studies in the group of healthy children, the frequency of the $\mathrm{C}$ allele was registered almost 1.5 times more often, and the T allele - 2 times less often. The distribution of genotypes of Chinese children with excess and normal body weight was: SS $33.3 \%$ and $34.1 \%$; CT $-48.1 \%$ and $48.9 \%$; TT $-18.4 \%$ and $16.9 \%$. When comparing our results of the study of the ACTN3 gene polymorphism (rs1815739) in healthy children, the homozygous variant of the $\mathrm{C} / \mathrm{C}$ genotype was registered 2 times more often, the heterozygous variant of the $\mathrm{C} / \mathrm{T}$ - 1.5 times more often, and the homozygous variant of the T/T genotype - 4 times less often [8].

In Spain Thomas Yvert et al. conducted a study of the polymorphism of ACTN3 gene (rs1815739) in children with cystic fibrosis, taking into account such indicators of lungs ventilation function as $\mathrm{FEV}_{1}$ and FVC. However, these scientists did not find significant differences in the distribution of homozygous or heterozygous genotypes compared with healthy children. Also in this study, no dependence of external respiration function on the allelic or genotypic distribution of the ACTN3 gene polymorphism (rs1815739) study or any other correlation dependencies were observed in both children with cystic fibrosis and in healthy children. As shown in Figure in this article, in children with cystic fibrosis and in healthy children, the incidence of ACTN3 gene genotypes (rs1815739) was about $25 \%$ and $30 \%$ for the major homozygous RR genotype, $55 \%$ - 50\% for the heterozygous R/X genotype, and 20\% for both observation groups with minor homozygous X/X genotype. In comparison, the incidence of these genotypes almost coincides with the results of our study in a group of sick children. However, FVC and $\mathrm{FEV}_{1}$ in patients with bronchial asthma were significantly higher in the minor homozygous $\mathrm{T} / \mathrm{T}$ genotype and lower in the major homozygous $\mathrm{C} / \mathrm{C}$ genotype. The excellent results of these studies are associated both with various etiological factors and various pathogenetic mechanisms of bronchospasm in cystic fibrosis and bronchial asthma [13].

Peter J. Houweling et al. in his review summarized the data of modern results and showed that the ACTN3 R577X genotype was interconnected not only with indicators characterizing sports achievements, but also affected the aging processes, state of the musculoskeletal system, especially with hereditary progressive diseases of the muscular system. Indeed, the homozygous minor XX genotype of ACTN3 gene (rs1815739) polymorphism, which, although it indicates a deficiency of $\alpha$-actinin- 3 , but at the same time is associated with a longer life expectancy and 
lower blood pressure, has a protective effect in diseases of the V type glycogen accumulation, and also protects dystrophic muscles from damage, which can slow the progression of diseases of the muscular system [16].

\section{Conclusion}

1. The study of the distribution of allelic genes and genotypes of ACTN3 (actinin, alpha 3) polymorphism for rs1815739 showed that among children with bronchial asthma, the homozygous $\mathrm{C} / \mathrm{C}$ genotype was recorded in $37.7 \%$ of cases, heterozygous $\mathrm{C} / \mathrm{T}$ genotype in $40 \%$ of cases, homozygous T/T genotype in $22.3 \%$ of cases, while in healthy children, the frequencies of the homozygous $\mathrm{C} / \mathrm{C}(68 \%)$ and $\mathrm{T} / \mathrm{T}(4 \%)$ genotypes were significantly more frequent.

2. The indicators of external respiration function (forced vital capacity (FVC), forced expiratory volume at the 1 -second $\left(\mathrm{FEV}_{1}\right)$ in patients with a homozygous $\mathrm{C} / \mathrm{C}$ genotype were significantly lower than in patients with homozygous T/T genotype and were $2.69(1.9 ; 3.49)$ vs. $3.11(2.47 ; 4,14)$ and $2.06(1.6 ; 2.76)$ vs. $2.82(2.02 ; 3.51)$.

3. The potency of large and small bronchi, characterized by spirographic MEF25 and MEF75 indicators, was significantly better in children with bronchial asthma with homozygous T/T genotype than in children with $\mathrm{C} / \mathrm{T}$ and $\mathrm{C} / \mathrm{C}$ genotypes $(5.46(4.87 ; 6,31)$ and $2.36(1.89$; $3.32)$ against $4.54(3.69 ; 5.43)$ and $4.17(3.24 ; 5.44)$, and $1.88(1.10 ; 2.56)$ and $1.69(1.16 ; 2.02)$, respectively.

4. In children with bronchial asthma and the $\mathrm{C} / \mathrm{C}$ and $\mathrm{C} / \mathrm{T}$ genotypes of ACTN3 gene (actinin, alpha 3) rs1815739 with probable sufficient synthesis of alpha-actinin-3 protein in muscles, a stronger contraction of the respiratory muscles on inhalation is possible, and in patients with the T/T genotype, which encodes insufficient synthesis of alpha-actinin-3 protein in the muscles, the muscle contraction is probably less pronounced in asthma attacks, which can lead to less pronounced disorders of lungs ventilation capacity.

5. The study of ACTN3 (actinin, alpha 3) rs1815739 gene polymorphism showed that the $\mathrm{C} / \mathrm{C}$ and $\mathrm{C} / \mathrm{T}$ genotypes were associated with impaired lung ventilation in children with bronchial asthma.

Financing. The presented scientific study was performed within the scientific and research work of the Department of Faculty Pediatrics of Zaporizhia State Medical University "Optimization of differential diagnostics and treatment of allergic and other diseases in children of different ages" (state registration number - 0118U004254), 2018-2022. 


\section{Prospects for further researches}

In the future, we are planning to continue studying the patterns of distribution of allelic genes and genotypes of ACTN3 polymorphism for SNP (rs1815739) in children with bronchial asthma depending on their physical development.

\section{Conflict of interests: none.}

\section{References}

1. Volosovets, A.P., Krivopustov, S.P., Makuha, N.T., Kupkina A.V. (2016) Features of Bronchial Asthma in Children with Overweight and Obesity. CHILD`S HEALTH, 8 (68), 51-55. https://doi.org/10.22141/2224-0551.8.68.2015.75182.

2. Chumachenko, N.G. (2016) Clinical and Anamnestic Features of Bronchial Asthma in Children from an Ecologically Unfavorable Region, Perinatologiya i pediatriya, 3 (67), 98101.https://doi.org/ 10.15574 / PP.2016.67.98

3. Drannik, G. N. (2006) Clinical immunology and allergology: a manual for students, interns, immunologists, allergologists, medical doctors of all specialties, M, 552.

4. Global Strategy for Asthma Management and Prevention. Revised 2019 [Electronic

resource] /National institutes of health. National Heart, lung and Blood Institute. Revised 2019 Access mode: http://www.ginasthma.org. - Title from screen.

5. Sokolenko, V.N., Vesnina, L.E., Zhukova, M.Yu., Mishchenko, I.V., Tkachenko, O.V. (2019). Physiology of the respiratory system, Poltava, 160.

6. Okhotnikova, E.N., Sharikadze E.V. (2015) Bronchial asthma and allergic rhinitis in children under 6 years of age: features of the treatment of comorbid pathology, Perinatologiya i pediatriya, 7 (71), 111-116. https://doi.org/ 10.15574 / SP.2015.71.111

7. Pertseva, T.A., Konopkina, L.I. (2008) Fundamentals of the study of ventilation function of the lungs: clinical diagnostic value,Toolkit for doctors and students of medical universities, Dnepr, 66.

8. Zhang, Q., Cao Y., Chen J., Shen J., Ke, D., Wang X., Ji, J., Xu, Y., Zhang, W., Shen, Y., Wang, D., Pan, D., Wang, Z., Shi, Y., Cheng, S., Zhao, Y., Lu, D. (2019) ACTN3 Is Associated With Children's Physical Fitness in Han Chinese, Mol Genet Genomics, 294 (1), 47 56. https://doi.org/10.1007/s00438-018-1485-7. 
9. Lavoie, T. L., Dowell, M. L., Lakser, O. J., Gerthoffer, W. T., Fredberg, J. J., Seow, C.Y., Mitchell, R.W., Solway, J. (2009) Disrupting Actin-Myosin-Actin Connectivity in Airway Smooth Muscle as a Treatment for Asthma?.Proc Am ThoracSoc, 6 (3), 295-300. https://doi: 10.1513/pats.200808-078RM

10. Gransee, H.M., Mantilla, C.B., Sieck, G.C. (2012) Respiratory Muscle Plasticity. Compr Physiol, 2(2), 1441-1462. https://doi.org/ 10.1002/cphy.c110050

11. Pickering, C., Kiely, J. (2017) ACTN3: More than Just a Gene for Speed. Front. Physiol, 18 December. https://doi.org/10.3389/fphys.2017.01080

12. Tharabenjasin, P., Pabalan, N., Jarjanazi, H. (2020) Association of the ACTN3 R577X (Rs1815739) Polymorphism with Elite Power Sports: A Meta-Analysis, PLOS ONE, 30May, 20.https://doi.org/10.1371/journal.pone.0217390

13. Yvert, T., Santiago, C., Santana-Sosa, E., Verde, Z., MezGallego, F.G., LopezMojares, L., Prez, M. (2015) Polymorphisms in Children with Cystic Fibrosis, Pediatric Exercise Science, 27, 102-112. http://dx.doi.org/10.1123

14. Sorokina, E.Yu., Keshabyants, E.E., Denisova, N.N. (2019) The Study of Association of Gene Polymorphism with Sports Success and Risk of Alimentary-Dependent Diseases in Athletes Representing Cyclic Sports.Sports Medicine: Science and Practice, 9 (3), 41 - 48. https://doi.org/10.17238/ISSN2223-2524.2019.3.41.

15. Chen, W., Zhang, B., Li, Y., Liang, T. (2020) Association Between rs1815739 Polymorphism of ACTN3 Gene and Athletic Ability in Chinese Sprinters, Journal of Science in Sport and Exercise, 2, 113-119. https://doi.org/10.1007/s42978-020-00058-1.

16. Houweling, P.J., Papadimitriou, I.D., Seto, J.T., Laura, M.P., Del Coso, J., North, K.N., Lucia, A., Eynon, N. (2018) Is evolutionary loss our gain? The role of ACTN3 p.Arg577Ter (R577X) genotype in athletic performance, ageing, and disease. Human Mutation Wiley Online Library. https://doi.org/10. 1002/humu.23663 